\title{
Case of making maxillary palatal augmentation complete denture for patient with dysphagia after partial glossectomy
}

\author{
Hyung-Seok Kim, Ji-Young Park, Sun-Young Yim, Yu-Ri Heo, Mee-Kyoung Son* \\ Department of Prosthodontics, College of Dentistry, Chosun University, Gwangju, Republic of Korea
}

If complication arises after glossectomy which leads to trouble in forming food bolus or transfer of the food, it is possible that either food bolus may block the airway or dysphagia may occur as the food bolus goes down into the airway. To solve the issue, palatal augmentation prosthesis could be used. In this case, the patient with an oral cancer is having difficulties swallowing food after glossectomy. Through taking impressions of polishing surface of his denture referring his tongue movement, the complete denture for the upper jaw was created using the concept of palatal augmentation prosthesis. This new upper denture increases the palataltongue contact pressure, allowing the patient to perform better swallowing and better pronunciation. (J Dent Rehabil Appl Sci 2018;34(3):239-45)

Key words: glossectomy; dysphagia; swallowing disorder; palatal augmentation prosthesis

\section{서론}

전체 암 발생 빈도의 약 $3-4 \%$ 를 차지하는 구강암 중 설암은 약 $45 \%$ 로 가장 높은 빈도를 차지하고 50 - 70 대 연령의 남성에서 주로 호발한다. ${ }^{1}$ 설암은 혀와 근접한 경부 림프절 level I, II, III에 주로 전이된다고 알려져 있 으며, 이를 제거하기 위해 선택적 경부 청소술(selective neck dissection, SND) 중 하나인 상견갑설골근 경부 청 소술(supraomohyoid neck dissection, SOND)이 가장 흔하게 시행되고 있다. 설암이 발생된 경우, 부분 혹은 완전 혀 절제술(partial or total glossectomy)을 시행하게 되고, 이로 인해 환자는 연하, 발음, 저작 기능에 장애를 겪게 된다. ${ }^{3-5}$

연하는 구강단계, 인두단계, 식도단계의 3단계로 이루 어진다. 그중 첫번째 단계인 구강단계에서 혀는 볼과 함 께 작용하여 식괴를 치아의 교합면에 위치하도록 하여

*Correspondence to: Mee-Kyoung Son

Professor, Department of Prosthodontics, College of Dentistry, Chosun University 303, Philmoon-daero, Dong-gu, Gwangju, 61452, Republic of Korea Tel: +82-62-220-3825, Fax: +82-62-227-2363, E-mail: son0513@chosun.ac.kr Received: June 18, 2018/Last Revision: July 12, 2018/Accepted: July 27, 2018
저작에 도움이 되게 할뿐만 아니라, 구개와 접촉하여 식 괴를 삼키기 쉬운 형태로 만들고 후방으로 이동시키는 역할을 한다. 혀의 전방 $2 / 3$ 부위는 연하의 초기단계에서 중요한 반면, 후방 $1 / 3$ 부위는 식괴를 식도로 밀어서 내 려보내기 위한 압력을 형성하는데 중요한 역할을 한다. ${ }^{4}$

만약 혀의 부분 또는 완전 절제술로 인해 식괴의 형성 이나 이동에 장애가 생기는 경우, 음식 섭취가 어렵거나 식괴가 기도를 막기도 하고 기도를 통해 폐로 흡인될 수 도 있는 연하장애(연하곤란, 삼킴장애)가 발생할 수 있 다. 특히 노인환자에서는 노화 또는 영양결핍에 의하여 연하와 관련된 목 주위 근육의 부피나 근력 감소를 동반 하는 경우가 빈번하며 혀의 힘 또한 감소되어 있으므로 70세 이상에서 연하장애의 빈도가 높게 나타나고 있다. 이러한 상황에 더하여 환자가 무치악으로 저작기능이 소 실되고 구강암 등으로 인해 혀 절제술이 시행되었다면 저 작 및 연하장애로 인한 심각한 문제에 당면하게 된다. ${ }^{6,7}$

Copyright@ 2018 The Korean Academy of Stomatognathic Function and Occlusion. (c) It is identical to Creative Commons Non-Commercial License. 
연하장애는 식괴의 기도폐쇄로 인한 질식뿐 아니라 침이 나 음식이 기도를 통해 폐로 넘어감으로써 흡인성 폐렴 의 원인이 되며, 이로 인해 노인환자는 사망에 이르게 될 수도 있다. ${ }^{7}$ 따라서, 이러한 경우 도움을 주는 장치가 필 요한데, 이를 위해 혀의 가동범위가 적거나 혀 절제술로 인해 혀가 구개에 접촉하지 않은 환자에서 발음이나 저 작, 연하에 도움을 주는 장치를 구개 증대 보철물(PAP; Palatal Augmentation Prosthesis)이라고 부른다. ${ }^{8}$

본 증례의 환자는 구강암으로 혀의 좌측 부분 절제술 후 음식을 삼키기 어렵다는 주소로 내원하였다. 혀의 기 능 운동을 인기한 상악의 연마면 인상을 채득하여, 구개 증대 보철 개념을 활용한 상악 총의치를 제작하였으며, 구개-혀 접촉 압력이 증가되어 연하 및 발음에 양호한 결 과를 얻었기에 보고하고자 한다.

\section{증례보고}

만 69세의 남자 환자가 음식을 삼키기 힘들고 치아가 상실된 부분을 보철수복하고 싶다는 주소로 내원하였 다. 환자는 15 년 전 설암으로 인해 좌측 혀 부분 절제술 (left partial glossectomy)과 하악골 부분 절제술(partial mandibulectomy), 상견갑설골근 경부청소술(supraomohyoid neck dissection, SOND) 후 전측 대퇴 피판 (anterolateral thigh flap) 및 전완 피판(forearm flap)을 이용해 재건하는 치료를 받은 병력이 있다. 초진 시 환자
는 상악 임시의치를 장착 중이셨으며 구내 검사 및 방사 선 사진 판독을 시행한 결과, 좌측 하악골 부분 절제 부 위의 각화 조직과 좌측 혀 부위의 반흔 조직이 관찰되었 고 \#33,47는 이차 우식, \#34는 잔존 치근 및 우식, \#44 는 심한 우식 상태였다(Fig. 1).

임플란트를 이용한 보철수복은 치료계획을 위한 상담 시 원치 않았으나, 추후 임플란트를 이용한 보철수복을 하더라도 입천장을 덮는 의치가 기능적으로 필요한 것으 로 보여 상하악 가철성 의치로 수복하기로 하였다. 연하 시 부분 절제된 혀가 구개측에 잘 접촉하지 않아 발음과 연하의 문제가 발생하고 있으므로, 상악은 구개 증대 보 철물의 형태를 갖는 총의치를 제작하기로 계획하였고 하 악은 \#33,34,44,46 발거 후 \#43-45 surveyed crown 및 가철성 국소의치를 제작하기로 계획하였다. 또한 좌측의 의치상은 반흔 조직의 전방까지만 조직 피개하도록 계획 하였다.

통상적인 방법으로 의치를 제작하는 과정 중, 하악 surveyed crown 수복 후 기능 인상 채득과정에서는 좌 측은 반흔 조직의 전방까지만 조직을 피개 할 계획으로 \#35부위까지만 기능인상 채득을 시행하였다.

납의치 시적 후 혀 운동을 인기하기 위하여 상악 연마 면 인상 채득을 시행하였다. 조직조정재(Tempo, Lang Dental, Wheeling, USA)를 구개측 연마면에 적용하여 구강 내 시적 후, 연하 운동 및 “E, ᄃ, ㄱ, ᄀ" 발음을 유 도하여 혀의 기능 운동을 인기하였다(Fig. 2, 3). ${ }^{3}$
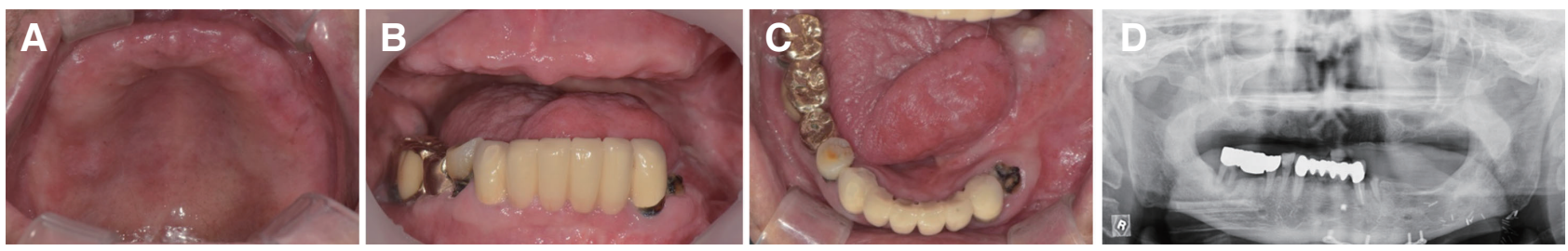

Fig. 1. Initial intraoral photographs. (A) Occlusal view of maxillary arch, (B) Frontal view of maxillary \& mandibular arch, (C) Occlusal view of mandibular arch, (D) A panoramic radiography.
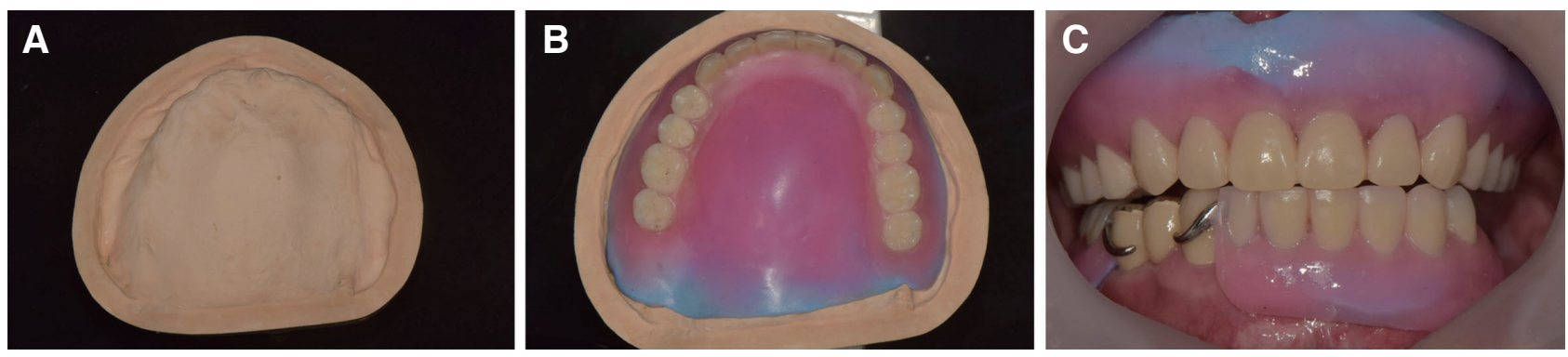

Fig. 2. (A) Master cast, (B) Wax denture, (C) Wax denture try in. 

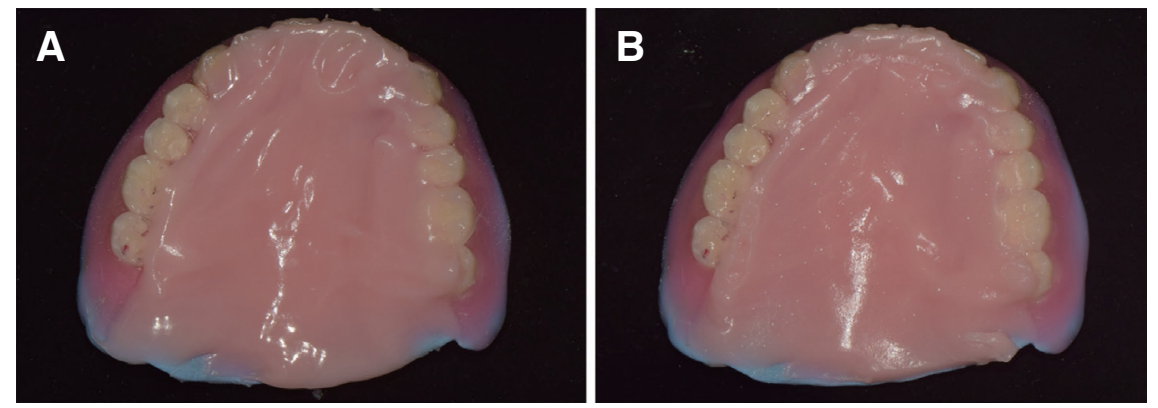

Fig. 3. (A) Application of tissue conditioner before polished surface impression, (B) After polished surface impression.
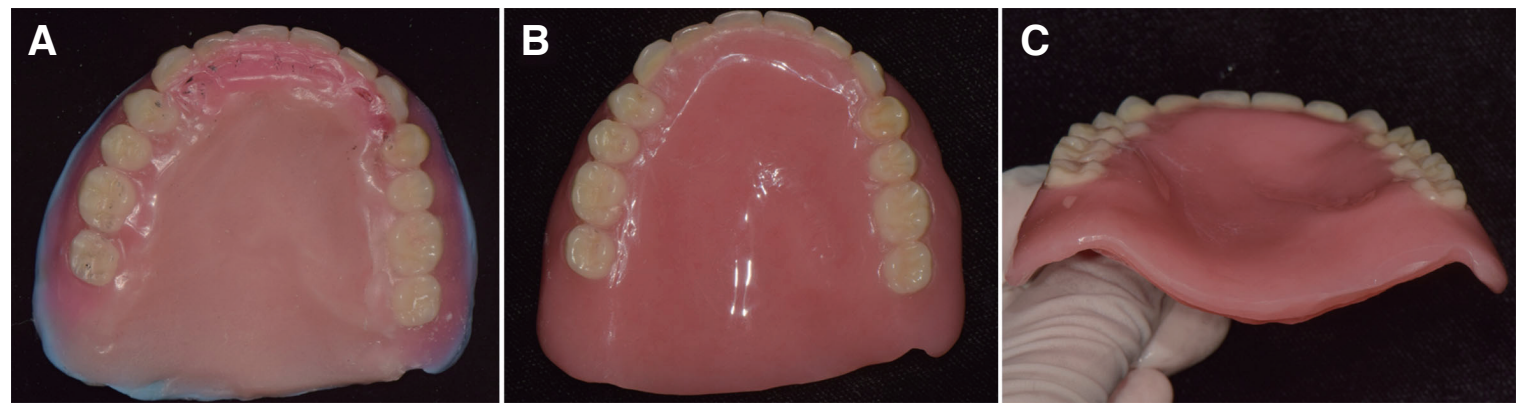

Fig. 4. (A) Upper wax denture after trimming tissue conditioner, (B, C) Occlusal \& rear view of cured upper complete denture with polished surface impression technique.

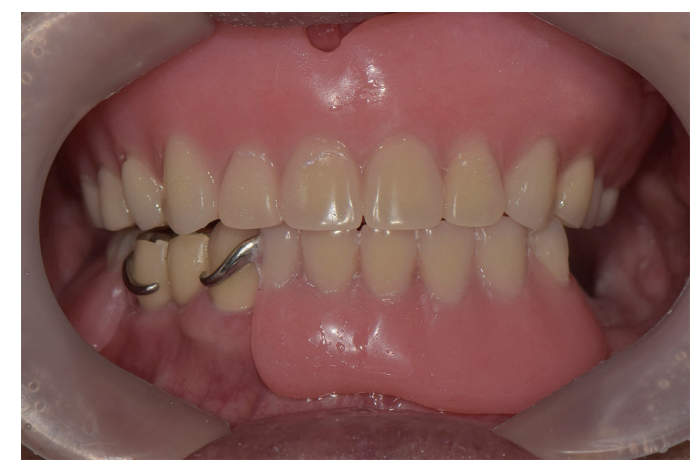

Fig. 5. Upper \& lower denture delivery.

이후 통상적인 방법으로 의치 제작을 완성하여 구강 내에 장착하였고, 원활한 사용여부 체크를 위해 구개-혀 압력 측정 및 발음을 평가하였다(Fig. 4, 5). 구개-혀 압력 측정을 위해, 연하 시 혀가 구개에 접촉할 때 JMS 혀 압 력 측정기(JMS Co. Ltd, Hiroshima, Japan)로 최대 혀 압 력을 측정하였다(Fig. 6, 7). 개선된 정도를 평가하기 위해 무치악 상태와 납의치 시적 시(연마면 인상 전), 의치 장 착 직후, 의치 장착 2 주 후에 각각 2 번씩 측정하여 평균 을 계산하였다(Table 1). 연마면 인상 전 납의치 시적 시 보다 의치 장착 후의 구개-혀 압력이 평균 $3.80-4.20 \mathrm{kPa}$ 만큼 증가되었음이 관찰되었다.

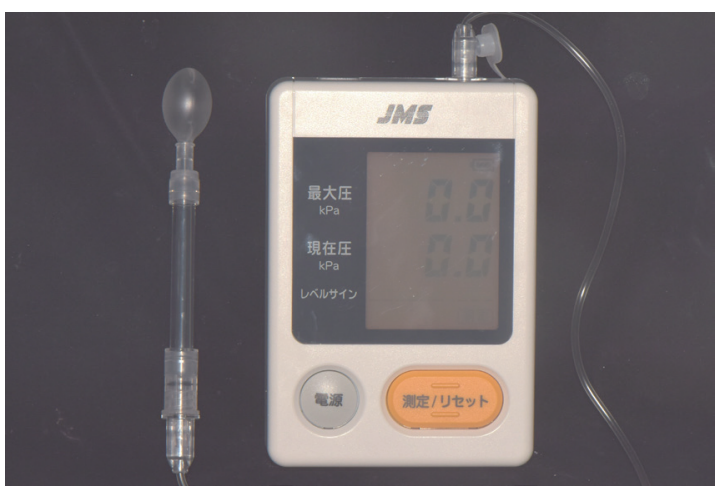

Fig. 6. A tongue pressure-measuring device (JMS tongue pressure measurement device ${ }^{\mathrm{TM}}$ ).

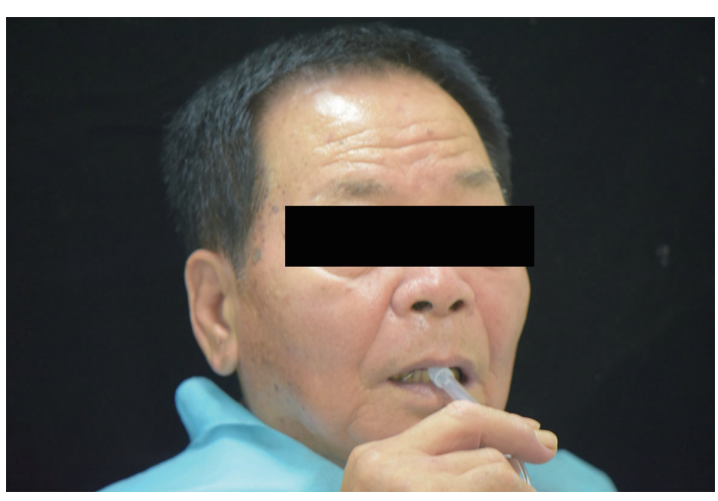

Fig. 7. The tongue pressure test. 
Table 1. Result of the tongue pressure test

\begin{tabular}{lccc}
\hline \multicolumn{1}{c}{ Measurement period } & $\begin{array}{c}\text { Primary measurement } \\
(\mathrm{kPa})\end{array}$ & $\begin{array}{c}\text { Secondary measurement } \\
(\mathrm{kPa})\end{array}$ & $\begin{array}{c}\text { Mean } \\
(\mathrm{kPa})\end{array}$ \\
\hline Edentulous state & 12.1 & 13.0 & 12.55 \\
Wax denture try-in before polished surface impression & 17.1 & 18.0 & 17.55 \\
Immediately after denture delivery & 22.7 & 20.8 & 21.75 \\
2 weeks after denture delivery & 21.7 & 21.0 & 21.35 \\
\hline
\end{tabular}

\section{고찰}

급격한 노인인구 비율의 증가에 따라 우리나라는 2026 년에는 만 65 세 이상의 노인인구가 총인구의 $20 \%$ 이상을 차지하는 초고령 사회로 진입할 것으로 예측되고 있다. ${ }^{6}$ 다른 나라와 비교하여 매우 빠른 초고령화로 진입하고 있으며 빠르게 발달된 의학기술 덕분에 수명이 증가되어 자연스레 노인의 건강 및 삶의 질 등에 관심이 급격하게 증가되어 왔다. ${ }^{6}$ 특히 식생활은 삶과 직접적으로 연관되 며 노인에게 연하장애는 흔히 일어날 수 있는데, 이러한 연하장애는 영양결핍 및 질식이나 흡인성 폐렴의 원인이 되며 질식으로 인한 갑작스런 죽음에 이르게 될 수도 있 다. ${ }^{78}$ 연하장애의 원인은 다양하지만, 치과에서 흔히 관 찰되는 연하장애의 원인으로는 부분 또는 완전 혀 절제 술과 혀 근육 약화에 따른 혀의 움직임 제한이 있다. ${ }^{9}$

설암으로 인해 부분 혀 절제술을 시행하였거나, 노화 에 의한 혀의 움직임 제한 등이 있는 환자에서 혀가 구개 에 접촉할 수 있도록 하는 구개 증대 보철물(PAP)의 제 작을 통해 연하장애를 해결할 수 있다고 보고되고 있다. ${ }^{9}$ Toyoshita 등 ${ }^{10}$ 은 상악 총의치 환자 10 명을 대상으로 의 치상 구개 부위 두께가 $1.4 \mathrm{~mm}$ 와 $2.8 \mathrm{~mm}$ 인 두 개의 의 치를 각각 착용하게 한 후 연하 시 혀의 움직임 및 소리를 측정하여 연하 능력을 평가하였고, 구개 부위가 두꺼운 의치상에서 혀 압력이 더 커서 연하 작용에 더 유리함을 보고하였다. Marunick와 Tselios ${ }^{5}$ 는 혀 절제술 후 연하장 애가 있는 환자들을 구개 증대 보철물로 수복한 여러 연 구들을 조사한 결과, 총 42명 중 36명에서 연하장애가 개 선된 것을 확인할 수 있었다. 물론 각각의 연구들의 환자 개개인의 다양성이 존재하는데다 혀 절제술 과정에 따른 장애의 정도가 분류되지 않았고 측정방법이 표준화된 것 도 아니지만, 대부분의 연구들에 의해 구개 증대 보철물 이 연하장애를 개선시킬 수 있다는 점이 긍정적으로 평 가되어 왔다. ${ }^{11-14}$
Ohno 등 ${ }^{11,12}$ 은 설하신경이 손상되어 연하장애가 있는 환자들에서 조직조정재를 사용하여 연하하는 동안 혀 기능 운동을 인기하여 구개 증대 보철물을 제작하였고, Abdulhadi ${ }^{13}$ 는 우측 혀 부분 절제된 환자에서 통상적인 방법으로 완성된 의치에 구개 증대를 위해 조직조정재로 기능 인상 채득하여 추후 아크릴릭 레진으로 교체하였 다.

본 증례의 환자는 혀의 좌측 부분 절제술로 혀의 움직 임이 저하되어 있고 상악의 오랜 기간 임시의치 상태로 인해 연하에 어려움이 있었다. 따라서 상악 무치악 치료 를 위한 총의치 제작 시, 혀의 움직임을 인기한 연마면 인 상을 채득하여 구개 증대 보철물을 제작하고자 하였다. 연마면 인상 채득할 때 먼저 연하 운동을 유도하여 혀의 움직임을 인기한 후, “E, ᄃ” 발음을 통해 혀 전방부위 기능 인상을, “ヨ, ᄀ ” 발음을 통해 혀 후방부위 기능 인 상을 각각 채득하였다. ${ }^{3}$

일반적인 환자와 혀 절제술 환자의 상악 연마면 인상 을 비교한 결과, 일반적인 환자에서는 전반적으로 구개 전방 및 측방부위 인상재의 두께가 매우 얇았고 구개 중 앙에서부터 후방부위로 갈수록 인상재가 더 많이 남아 있었다. 연하 시 구개 전방과 측방부위에서 혀가 긴밀하 게 접촉하면서 인상재를 구개 중앙 및 후방부위로 이동 시킨 것으로 보인다. Ono 등 ${ }^{15}$ 은 평균 28 세의 정상인 10 명을 대상으로 연하 시 혀 압력 패턴을 분석하였는데, 혀 는 구개 전방부위에 가장 먼저 접촉했을 뿐만 아니라 가 장 오랫동안 접촉했었던 반면에, 구개 후방부위에는 마 지막에 접촉했고 가장 짧은 시간 동안만 접촉했다. 연하 시 구개에 혀가 접촉하는 순서는 구개 전방 - 구개 측방 - 구개 중앙 - 구개 후방 순이었고, 구개 전방부위에서 최 대 혀 압력이 가장 높게 나타났으며 구개 후방부위에서 가장 작게 나타났다. 이 측정 결과는 일반적인 환자의 상 악 연마면 인상 형태와 유사한 양상을 보인다. 반면에 혀 절제술 환자의 경우 접촉 압력의 저하로 인상재의 두께 

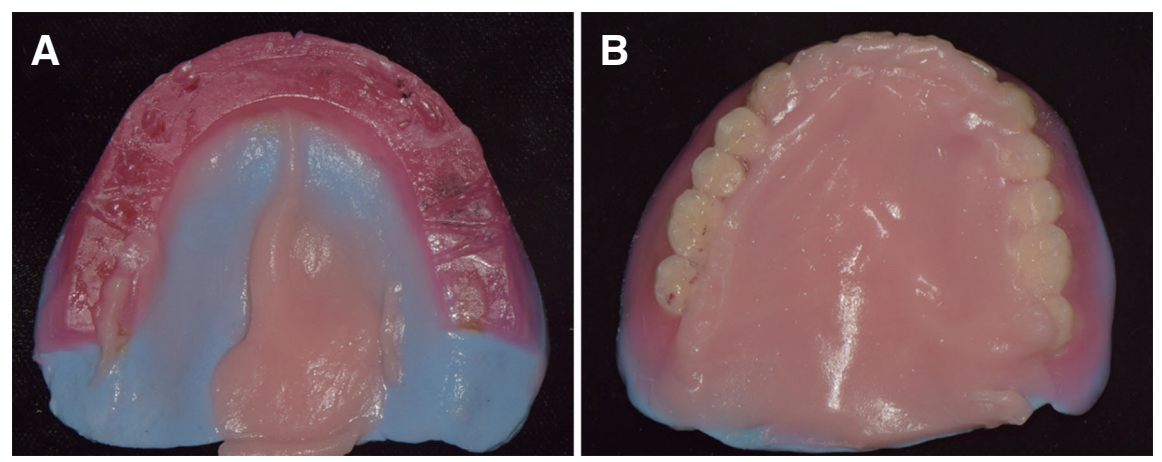

Fig. 8. Upper wax denture after polished surface impression. (A) Normal patient without dysphagia, (B) Patient with partial glossectomy.

가 구개 전방 및 측방부위를 포함하여 전반적으로 두껍 게 나타났으며, 좌측 혀 부분 절제에 의한 좌측 구개-혀 압력 감소로 인해 좌측 측방부위 인상재가 두꺼워서 좌 우가 크게 불균형한 양상으로 나타났다(Fig. 8).

Ono 등 ${ }^{15}$ 의 연구에 따르면 연하 시 정상인의 최대 혀 압력의 평균은 구개 부위별로 19.4 - $25.6 \mathrm{kPa}$ 사이에 분 포하였는데, 본 증례 환자의 연마면 인상 후의 구개-혀 압력 측정값 $(21.35-21.75 \mathrm{kPa})$ 이 정상인의 수치와 근접 한 결과를 보였다.

연마면 인상을 채득한 최종의치를 장착한 초기에는 두 껍고, 불규칙한 표면의 구개부로 인한 불편감을 호소하 였으나, 약 4주 경과 후에는 특별한 불편감을 나타내지 않았다. 연마면 인상 채득 후, 구개-혀 압력이 증가하였 으며, 환자는 연하 및 발음에 대해 보철물 장착 전 또는 연마면 인상 전 보다 개선되었다고 평가하였으며 만족하 였다.

\section{결론}

혀 절제술로 인해 혀의 형태가 비정상적인 경우에 구 개-혀 압력이 감소하여 연하장애가 발생할 수 있다. 혀 가 구개에 접촉하도록 하게 하는 구개 증대 보철물은 이 러한 연하장애를 개선시키는데 사용될 수 있다. 악성종 양으로 인한 기능적인 문제를 갖는 이 같은 환자 외에도 노화에 의한 구강 및 구강주위 근력의 저하로 연하장애 를 경험하는 노인환자들이 증가하고 있다. 따라서, 노인 환자 맞춤형 보철치료, 즉 단순히 구강의 해부학적 형태 를 수복하는 보철치료보다는 구강기능재활과 회복을 고 려한 보철물의 제작으로 치료 패러다임의 변화가 필요할 것이다.

\section{ORCID}

Hyung-Seok Kim https://orcid.org/0000-0001-77144350

Ji-Young Park https://orcid.org/0000-0001-9169-851X Sun-Young Yim https://orcid.org/0000-0001-7874-8543

Yu-Ri Heo https://orcid.org/0000-0002-1806-3822

Mee-Kyoung Son https://orcid.org/0000-0001-92251744

\section{References}

1. Choi SW. Clinical diagnosis of oral cancer. J Korean Dent Assoc 2011;49:136-45.

2. Joo YH, Sun DI, Shin JH, Shin JH, Lee CH, Cho $\mathrm{SH}$, Kim MS. The results of treatment in clinical NO oral tongue cancer. Korean J Otorhinolaryngol Head Neck Surg 2007;50:929-34.

3. Yoon JY, Lee SH, Lee JY, Oh NS. Prosthetic rehabilitation for a glossectomy patient - a clinical report. J Korean Acad Prosthodont 2013;51:347-52.

4. Balasubramaniam MK, Chidambaranathan AS, Shanmugam G, Tah R. Rehabilitation of glossectomy cases with tongue prosthesis: a literature review. J Clin Diagn Res 2016;10:ZE01-ZE04.

5. Marunick M, Tselios N. The efficacy of palatal augmentation prostheses for speech and swallowing in patients undergoing glossectomy: a review of the literature. J Prosthet Dent 2004;91:67-74.

6. Kwag JM, Park II, Son MK. Suggestion for understanding and activation of the nursing home dentist 
system. Oral Biol Res 2017;41:127-33.

7. Sakai K, Nakayama E, Tohara H, Kodama K, Takehisa T, Takehisa Y, Ueda K. Relationship between tongue strength, lip strength, and nutrition-related sarcopenia in older rehabilitation inpatients: a crosssectional study. Clin Interv Aging 2017;12:1207-14.

8. Sura L, Madhavan A, Carnaby G, Crary MA. Dysphagia in the elderly: management and nutritional considerations. Clin Interv Aging 2012;7:287-98.

9. The glossary of prosthodontic terms. J Prosthet Dent 2017;117:e1-e105.

10. Toyoshita Y, Koshino H, Hirai T, Matsumi T. Effect of wearing a palatal plate on swallowing function. J Prosthodontic Res 2009;53:172-5.

11. Ohno T, Fujishima I. Palatal and lingual augmentation prosthesis for patients with dysphagia and functional problems: a clinical report. J Prosthet
Dent 2017;117:811-13.

12. Ohno T, Ohno R, Fujishima I. Effect of palatal augmentation prosthesis on pharyngeal manometric pressure in a patient with functional dysphagia: a case report. J Prosthodont Res 2017;61:460-3.

13. Abdulhadi LM. Different techniques for palatal augmentation in partially glossectomized patients. A report of two cases. Open Access Scientific Reports 2012;1:391.

14. Robbins KT, Bowman JB, Jacob RF. Postglossectomy deglutitory and articulatory rehabilitation with palatal augmentation prostheses. Arch Otolaryngol Head Neck Surg 1987;113:1214-8.

15. Ono T, Hori K, Nokubi T. Pattern of tongue pressure on hard palate during swallowing. Dysphagia 2004;19:259-64. 


\section{부분 혀 절제술로 인해 연하 장애가 있는 환자에서 상악 구개 증대 총의치 제작 증례}

김형석, 박지영, 임선영, 허유리, 손미경*

조선대학교 치과대학 치과보철학교실

만약 혀 절제술로 인해 식괴의 형성 및 이동에 장애가 생기는 경우, 식괴가 기도를 막거나 기도로 흡인되는 연하장애가 발생할 수 있으며, 이런 경우에 구개 증대 보철물은 도움이 될 수 있다. 구강암으로 인해 부분 혀 절제술을 받은 후 음식 물을 삼키기 어렵다는 주소로 내원한 환자에게 혀의 기능 운동을 인기한 상악의 연마면 인상채득을 통해 구개 증대 보철 개념을 활용한 상악 총의치를 제작하여, 구개-혀 접촉 압력을 증가시켜서 연하 및 발음에 양호한 결과를 얻을 수 있었다.

(구강회복응용과학지 2018;34(3) :239-45)

주요어: 혀 절제술; 연하 곤란; 삼킴 장애; 구개 증대 보철물

*교신저자: 손미경

(61452)광주광역시 동구 필문대로 303 조선대학교 치과대학 치과보철학교실

Tel: 062-220-3825 | Fax: 062-227-2363 | E-mail: son0513@chosun. ac. kr

접수일: 2018년 6월 18일 | 수정일: 2018년 7월 12일 | 채택일: 2018년 7월 27일 